\title{
Audrye Wong
}

\section{PEDDLING OR PERSUADING: CHINA'S EGONOMIC STATECRAFT IN AUSTRALIA}

\begin{abstract}
With the globalization of Chinese capital, economic statecraft has become an increasingly prominent component of China's foreign policy. In this article, I examine China's use of economic inducements in developed democracies, a topic of growing concern for policymakers, focusing on the case of Australia. I show how Beijing's attempts to coopt public voices and influence Australia's foreign policy using non-transparent political donations and academic funding generated a strong backlash. At the same time, economic interdependence has provided a buffering effect, with key domestic actors in Australia advocating for cooperative relations, although this effect can in turn be limited by Beijing's coercive economic tactics. My findings underline the reputational costs of certain approaches to economic statecraft, the value of building supportive coalitions, and the challenges faced by China's authoritarian state capitalist model. They also highlight the impacts of globalized Chinese capital in developed democracies, including the resilience and vulnerabilities inherent in democratic political processes.
\end{abstract}

\section{Keywords}

economic statecraft, China, Australia, inducements, political donations, economic interdependence, coercion

\section{INTRODUCTION}

With the globalization of Chinese capital, there has been increasing attention among scholars and policymakers to the political and security implications for growing economic interdependence with China. Beyond investment and infrastructure projects in developing countries, Chinese capital has also become an increasingly prominent presence in developed and wealthy countries. This has expanded the potential for Beijing to employ economic statecraft-the use of economic tools to pursue political goals - as a tool for achieving its foreign policy interests.

In this article, I examine the political impacts of China's economic statecraft, in particular positive inducements, in developed democracies, which has been a source of growing concern for policymakers. I focus on Australia, which presents an interesting case study. While it is a US ally and is considered a high-income liberal democracy, Australia also has close economic linkages with China and a strong interest in maintaining cooperative political ties.

Managing the economic and security elements of the Australia-China relationship has been a major — and polarizing — debate. Recent tensions have stemmed from Beijing's 
perceived attempts to use non-transparent economic inducements through CCP-linked proxies to increase political involvement in Australia's domestic politics, coopt public voices, and shape the direction of foreign policy discourse about China. These efforts have generated strong public backlash against China, along with greater political scrutiny of China's overseas economic activities.

At the same time, several domestic constituencies-economic and political-remain vested in cooperative relations. Growing economic interdependence between the two countries has increased China's strategic importance for Australia's foreign policy orientation. This has created internal divisions regarding how to manage the relationship with Beijing, with economic benefits juxtaposed with political risks. Despite the polarized debate between the security and intelligence establishment on the one hand and more engagement-oriented actors on the other, the Australian government has largely sought to keep bilateral ties on track and has recognized the benefits of attracting Chinese capital, although Beijing's efforts at economic coercion have also undermined such arguments.

This article tackles a key question raised in this special issue: What are the impacts of Chinese capital abroad, and how have recipient countries responded? My findings underline the reputational costs of certain approaches to economic statecraft-when inducements are employed in non-transparent ways that do not conform with political norms and processes (Wong 2019, 2021). This points to the sources of reputation deficits often suffered by Chinese capital abroad, as also discussed by Shi and Seim (2021). Moreover, the impacts of Chinese outward capital are mediated and exacerbated by widespread external perceptions of cohesive and authoritarian state control over outbound capital (even if these are not always true, as suggested by Ye and others in this issue. This further contributes to a negative and skeptical view of China's economic activities. As a result, Chinese capital, whether politically or commercially driven, often generates backlash and gets caught up in local politicization.

My findings also point to the buffering effects of economic interdependence, which generates a coalition of domestic stakeholders who benefit from economic relations with China, and actively advocate for a more cooperative foreign policy toward Beijing. Additionally, the increasingly important role of Chinese capital and China's economy, not just in developing countries but also in developed economies, has meant that it is difficult for countries to reject outright incoming Chinese financing, despite concerns that such capital may be redirected for Beijing's geopolitical purposes or be used to interfere with domestic democratic processes. On the flipside, a turn by Beijing to coercive economic tactics has highlighted the vulnerabilities of such interdependence and limited the buffering effects of pro-China constituencies in Australia.

Finally, this article serves as a complement to other studies of China's economic statecraft across different political systems and in developing countries, both in this special issue and elsewhere (e.g. see Norris 2016; Wong 2019). My findings highlight the inherent dilemmas for developed democracies when it comes to accepting Chinese capital, including the vulnerabilities and resilience afforded by open democratic political systems. This has important implications, as China's economic reach increasingly turns toward the United States, Canada, and European countries, not least under the ambitious Belt and Road Initiative (BRI). 
With the expansion of China's economy and the globalization of Chinese capital, there has been increasing attention on Beijing's potential use of economic statecraft to achieve its foreign policy goals. While security studies scholarship has focused largely on sanctions (Baldwin 1971, 1985; Drezner 1999; Pape 1997), including the potential coercive effects of trade dependence on China, such as import or export restrictions (Fuchs and Klann 2013), positive inducements present an important and growing component of economic statecraft (Abdelal and Kirshner 2000; Copeland 1996; Davis 1999; Long 1996; Mastanduno 2000; Newnham 2002; Skålnes 2000).

China's overseas economic activities, along with its announcement of the US $\$ 1.3$ trillion BRI, have sparked greater attention to (and concern over) the potential geopolitical implications of its expanding economic clout. Economic inducements create what Hirschman calls an "influence effect," in which vested economic interests form a "commercial fifth column" that "exert[s] a powerful influence in favor of a "friendly' attitude toward the sender state" (Hirschman 1945, 26-29). By strengthening and mobilizing certain interest groups within the target country, inducements help to create domestic political coalitions that alter and reshape the target country's preferences and interests in favor of the sender state (Kirshner 1997), similar to the way domestic coalitions and sectoral interests shape a country's foreign policy and grand strategy (Davis 2009; Narizny 2007; Solingen 1998).

This relates to a parallel strand of research that has discussed the broader spillover effects of economic interdependence (or dependence) on political and security outcomes-for instance, whether countries that have closer trade relations with China are more likely to support China's positions on human rights and other issues (Flores-Macias and Kreps 2013; Kastner 2014). Scholarship on the broader linkages between economic interdependence and international security has viewed economic relations as a constraint against war (Mansfield and Pollins 2001, 2003; Papayoanou 1999).

Yet economic capabilities do not always translate into political influence. There has been a longstanding debate on the effectiveness of economic statecraft, including coercive sanctions (Baldwin 1985; Baldwin and Pape 1998; Kirshner 2002; Pape 1997) and positive inducements (Davis 1999; Kahler and Kastner 2006; Kastner 2007; Nincic 2011; Norris 2016; Papayoanou and Kastner 2000). Despite China's apparent economic clout, it has not been particularly effective at changing the political preferences of South-East Asian countries (Goh 2014). More recent work has emphasized how inducements that corrupt or subvert political processes often encounter backlash in countries where there are accountability mechanisms constraining elite behavior (IWong 2019, 2021).

This article builds on these frameworks to examine Chinese capital in the context of economic statecraft and its geopolitical impacts, including the differing responses in Australia to perceived illegitimate versus legitimate inducements. As the case evidence will show, efforts at peddling influence through non-transparent economic inducements incurred backlash and reputational costs, although the degree of pushback was buffered by broader economic interdependence and the formation of domestic constituencies advocating for a cooperative relationship. 
First, I analyze how China has attempted to influence Australia's foreign policy, in particular through political donations and academic funding, with the aim of coopting public voices and shaping the direction of intellectual discourse about China. However, this soon generated a strong public backlash against China. The presence of robust institutional mechanisms enabled open debate and transparent reporting on politicians linked to Beijing's payroll. This pressured politicians to backtrack, and facilitated further institutionalization to increase resilience against foreign interference.

The Chinese government dangled inducements by exploiting vulnerabilities in Australia's democratic processes, including relatively lax campaign financing laws that did not require donors to be Australian nationals. At the same time, this targeting of individual political elites through less-than-transparent means bore many similarities to the transactional and under-the-table nature of aid and infrastructure projects often offered to developing countries (Wong 2019).

Australia's intelligence agency had flagged two major political donors, Huang Xiangmo and Chau Chak Wing, as having close connections to the Chinese Communist Party (CCP) and warned the leaders of Australian political parties that their donations might come with strings attached. For example, Chau is an Australian national and billionaire property developer who owns a CCP-linked newspaper in Guangdong and is a member of a provincial-level Chinese People's Political Consultative Conference (CPPCC), suggesting close governmental ties. From 2006 to 2016, he gave over A $\$ 4$ million to the three major political parties in Australia - the Liberal, Labor, and National Parties. ${ }^{1}$ Chau has access to high-level politicians on both sides of the political aisle. During a trip to Europe as Foreign Minister, former Prime Minister Kevin Rudd made a stopover in Guangdong (bypassing Beijing), leaving by the back door of his hotel to meet Chau in a limo sent by the Chinese businessman. ${ }^{2}$

Huang Xiangmo similarly donated almost $\mathrm{A} \$ 2.7$ million across political parties between 2012 and 2016. Until recently, he was president of the Australian Council for the Promotion of Peaceful Reunification of China (ACPPRC), a prominent instrument of China's United Front work, which aims to advance CCP interests by winning over friends and silencing perceived enemies of the Chinese state. Huang's donations meant that he often rubbed shoulders with top-level politicians in Australia. He was also a prominent figure in the Chinese-Australian community who was well connected with the Chinese embassy, and could often be seen seated next to the PRC ambassador at events. ${ }^{3}$ In an editorial for the Global Times, Huang wrote that the Australian Chinese community needed to learn "how to have a more efficient combination between political requests and political donations." $4 \mathrm{He}$ also publicly stated that "overseas Chinese realize that they need to make their voices heard in politics, to safeguard Chinese interests, and let Australian society pay more attention to the Chinese." 5

In the most publicized scandal, in 2016 a New South Wales (NSW) state senator, Sam Dastyari, was found to have very close ties with Huang Xiangmo. As the Australian Labor Party's NSW General Secretary and subsequently Senator, Dastyari was closely involved in fundraising, and Huang was an important donor. Huang and associated donors also helped Dastyari cover several thousand dollars of legal fees and travel bills. ${ }^{6}$ In June 2016, the Chinese businessman had canceled a promised $\$ 400,000$ 
donation to the Labor Party after its defense spokesperson criticized the sitting government's "ambiguous" policy on the South China Sea and called for the Australian military to conduct freedom of navigation operations. At a press conference the following day, standing next to Huang, Dastyari called for Canberra to refrain from involvement in the South China Sea disputes and respect Beijing's position, saying that "the Chinese integrity of its borders is a matter for China ... As a supporter, and a friend of China, the Australian Labor party needs to play an important role in maintaining that relationship and the best way of maintaining that relationship is knowing when it is and isn't our place to be involved."7 In addition, Dastyari made calls to expedite Huang's citizenship application, and provided counter-surveillance advice to Huang during a face-to-face meeting at the latter's mansion in October of the same year, telling him to leave his phone and have their conversation outside, as Australian security agencies were monitoring him. ${ }^{8}$

Huang was also able to parachute his allies (with similar links to the ACPPRC) into political positions. Six months after Huang and his associates made a \$500,000 donation to the NSW Labor Party in November 2012, Ernest Wong was placed into the Upper House seat formerly held by Eric Roozenthal, who then went on to work for Huang. Similarly, a month after making a \$60,000 donation, fellow ACPPRC member Simon Zhou was given a place on the Labor Party's senate ticket for the 2016 election. ${ }^{9}$ Observers note that the insertion of CCP proxies into political circles is still significant, even at the local and state levels, given the face time and networking connections with senior and federal-level politicians and party operatives. ${ }^{10}$ The Australian Security Intelligence Organization (ASIO) has thus far identified about 10 candidates at state and local government elections who were closely linked with Chinese intelligence services. ${ }^{11}$ While Chinese-Australians have the right to get involved in politics, the fact that any sufficiently prominent individual or successful businessperson would likely need to have political connections in China and community organizational support in Australia (now often controlled by CCP United Front organizations) makes it harder to disentangle the reach of the Chinese government.

CCP-linked money has also reached into universities and academic circles in Australia. Chau Chak Wing gave A $\$ 20$ million to the Business School at the University of Technology Sydney (UTS). Huang also donated A \$1.8 million to UTS, to set up the Australia-China Relations Institute (ACRI), replacing the now-defunct China Research Institute. Huang served as chairman of ACRI's board, and personally named former Foreign Minister Bob Carr to be ACRI's executive director. Carr has stated that ACRI "take[s] an unabashedly positive and optimistic view of the Australia-China relationship." 12 Feng Chongyi, a professor at the same university and a vocal CCP critic, has said that ACRI repeatedly dismissed his attempts to get involved. ${ }^{13}$ According to a senior Labor source, Carr has been "pushing for an aggressive pro-China position" among NSW Labor MPs. ${ }^{14}$ Through ACRI, Carr has brought Australian journalists on study tours around China, resulting in puff pieces presenting a gleaming image of China and repeating Party lines on the economic benefits of a peaceful bilateral relationship and ominous warnings should Canberra anger Beijing over the South China Sea and other issues (Hamilton 2018, 104-108).

Other Australian China experts have expressed concerns over ACRI's academic independence and criticized the institute for being a "propaganda vehicle" for the Chinese government, with limited transparency regarding its financial budget and 
activities (including meetings with CCP officials), and a preference for one-sided opinion pieces and fact sheets. One prominent academic has described the "monotony of Carr's China-Whatever comments." 15 Carr described Huang Xiangmo as being "well-informed on Chinese politics" and "unfairly victimized" by an ongoing "China panic" in Australia. He criticized current political leaders for "loose talk" and anti-PRC statements, and argued that there was no evidence of a coordinated CCP strategy to swamp Australia with Chinese money. ${ }^{16}$

\section{DEMOCRATIC VULNERABILITIES AND CHINA'S CARROTS}

In what ways has Beijing attempted to coopt domestic political actors in Australia through the use of economic carrots? Australia's arguable status as a canary in a coal mine - at the forefront of liberal democracies grappling with the implications of CCP political and economic activities_-makes it a salient case to further examine targeted domestic actors and the potential mechanisms of influence.

Through political donations, Beijing has been able to exploit potential vulnerabilities in open democratic systems. China has been skillful at targeting specific actors who occupy politically pivotal positions, yet are susceptible-and thus more receptive- to economic incentives.

Relatively small rates of political party memberships and the struggle to finance electoral campaigns make Australian politicians eager for generous donors. ${ }^{17}$ From the Chinese government's perspective, Sam Dastyari in particular was an appealing figure with whom to work, given his influential position as a power broker and fundraiser within the Labor Party. ${ }^{18} \mathrm{He}$ also belonged to the NSW Labor Right, a powerful political faction that could be compared with the Tammany Hall political machine in New York politics. ${ }^{19}$ Others have pointed to the NSW capital, Sydney, as a fairly corrupt town with a history of money politics where donors exert influence. ${ }^{20}$

As Australian politicians seek to engage with the growing Chinese-Australian communities, the need for campaign financing and grassroots machinery has given CCP-linked individuals more opportunities to influence political advocacy. For example, a Sydney MP, Craig Laundy, participated in CCP-organized protests against Japanese Prime Minister Shinzo Abe's visit to the Yasukuni Shrine, and apparently condemned Tibetan-led protest in Sydney as "thugs who attacked the Chinese consulate." 21

The Chinese government's strategy has been to make financial contributions to anyone who has a reasonable chance of winning office, over time making them more sympathetic to issues of interest to China and becoming a supporter of constructive and friendly relations with Beijing. ${ }^{22}$ For example, Sam Dastyari had been previously quoted in PRC media as saying that getting involved in territorial disputes in Asia was against Australia's national security interests, and he appeared at a Chinese community event in Sydney protesting then Prime Minister Tony Abbott's meeting with Shinzo Abe and praise of Japanese soldiers. ${ }^{23}$ In 2015, Dastyari also reportedly pressured a deputy Labor leader not to meet with a political activist during her visit to Hong Kong. ${ }^{24}$ During Senate committee hearings, Dastyari's intensive line of questioning toward senior foreign and defense policy officials reflected China's concerns. ${ }^{25}$

Senior and retired political figures also present a useful public voice for Beijing. The Chinese government has been particularly good — even compared with other countries — at 
entertaining top politicians and making them feel important through pomp and circumstance. ${ }^{26}$ Politicians leaving office have spent their careers in politics and earned less relative to their corporate peers, and can also suffer what observers call relevance deprivation syndrome, making opportunities such as consulting gigs, employment at Chinese corporations, or running an institute particularly attractive. ${ }^{27}$

Retired politicians also continue to be quoted in the news media, and provide access to current politicians. This makes them valuable assets for the Chinese government seeking to propagate a particular point of view. Despite the controversy over ACRI, Bob Carr is frequently quoted in the media, and his reputation as a respected former statesman remains largely intact among the general public, even if he has been dismissed by many elites. ${ }^{28}$ Beijing also skillfully worked with political figures seen as more favorable toward China. During his tenure as Foreign Minister, Carr advocated a less adversarial approach to China, and was wary of publicly tightening defense cooperation with the United States and Japan for fear of unnecessarily raising Beijing's hackles (Carr 2014, 142-145, 157, 218-220, 338).

Other top-ranking political figures have also been implicated. Former Trade Minister Andrew Robb pushed strongly for the China-Australian Free Trade Agreement (ChAFTA) to be sealed, despite criticisms about the potential benefits and concerns over the Australian labor market; Huang's company donated A \$100,000 to Robb's fundraising vehicle, including $\mathrm{A} \$ 50,000$ on the day ChAFTA was signed. Even before officially leaving his job, Robb took on an unspecified consulting position for A \$880,000 a year with Landbridge, a Chinese firm with links to the PRC government, which acquired the controversial lease of Darwin Port in 2015 (Hamilton 2018, 71-72, 116-118). ${ }^{29}$ Other high-ranking politicians and senior party leaders from across the political spectrum have attended fundraisers and activities linked to CCP-affiliated individuals. ${ }^{30}$

In these cases, it is unlikely that individual politicians are acting as Manchurian candidates; rather, the enticement of Beijing's carrots led to perhaps naive choices to associate with CCP-linked individuals, seeing it as part of usual electoral maneuvering before suffering the political consequences. ${ }^{31}$

\section{BACKLASH AND POLARIZATION}

However, CCP-linked political financing activities soon generated strong public and political backlash against China, involving open debate and extensive reporting on politicians linked to Beijing's payroll. Political, media, and public criticism pressured politicians to resign and backtrack from ties with China, as well as sparking a review process of Chinese donor influence and new foreign interference laws. ${ }^{32}$

Media reporting has publicized awareness of "cash for comment" instances and broader knowledge of CCP influence in Australia. Journalists have played significant and instrumental roles in uncovering details of the Dastyari scandal, Huang's and Chau's activities, the status of ACRI, and other United Front-related work about overseas Chinese students and Chinese-language media in Australia. ${ }^{33}$ Established institutional structures mean that journalists are also able to access and publish information about where the sources of political donations and which politicians are implicated. ${ }^{34}$ Scholars and former government officials have further chimed in through written analysis and 
media interviews. ${ }^{35}$ Criticism has centered on how the CCP has been undermining parliamentary sovereignty and interfering in Australian electoral processes through the use of financial inducements. ${ }^{36}$

In addition, political pressure and democratic processes led to domestic consequences for political figures ensnared in Beijing's influence peddling. After Sam Dastyari's comments on the South China Sea were reported, the senator quickly ducked the issue and backtracked, saying that he supported the Labor Party position and international rule of law. ${ }^{37}$ Politicians across political parties have openly criticized the situation (albeit with a tendency to attack individuals from the opposite side of the aisle). ${ }^{38}$ Facing political pressures, including from some voices within the Labor Party, Sam Dastyari resigned in December 2017. ${ }^{39}$ Ernest Wong, a local politician linked with Huang, also publicly cut institutional links to the businessman. ${ }^{40}$ Implicated leaders have been discounted within their political party; politicians themselves are now wary of accepting PRC-linked money, and decline invites to dinners and events with CCP-linked individuals that they might have attended a few years ago. ${ }^{41}$ Huang Xiangmo resigned as the chairman of ACRI's board, and the institute has made an effort to clarify its budget, stating that Huang's donation ran out in 2016 and that UTS has been responsible for operating costs since then. ${ }^{42}$

The Australian government also took a strong stance in criticizing China's political interference efforts, with Prime Minister Malcolm Turnbull controversially paraphrasing a famous Mao Zedong quote (although its authenticity has been questioned) to declare in Mandarin that "the Australian people [will] stand up" to China. ${ }^{43}$ In August 2016, the government commissioned a classified investigation on foreign interference in Australia, which found widespread political interference by the CCP. ${ }^{44}$ In December 2017, Canberra introduced a new set of foreign interference legislation, titled the National Security Legislative Amendment (Espionage and Foreign Interference) Bill 2017 and the Foreign Influence Transparency Scheme Bill 2017. These laws would ban foreign political donations, require those in Australian politics to declare links with foreign entities, and make it a crime to act covertly on behalf of a foreign principal to influence Australian political processes or against Australian national interests. ${ }^{45}$ These Bills were reviewed by the Parliamentary Joint Committee on Intelligence and Security (PJCIS), and members of the public (from academics to civil society to community organizations) made several submissions in response to the proposed legislation, which also stirred debate over freedom of press concerns. ${ }^{46}$ The law on covert foreign interference and espionage was passed in June $2018,{ }^{47}$ and the law banning foreign political donations was passed in November 2018.48

The presence of relatively robust democratic processes in Australia was key to facilitating political and legal pushback against the insidious political effects of Chinese capital. Observers have expressed confidence in the Australian political system, including the healthy response of media and governing institutions.$^{49}$ Others have discussed the importance of media reporting, transparency, and democratic institutions in making Australia more resilient to Beijing's political interference efforts, and the necessity of clear legal frameworks. ${ }^{50}$ In a testimony hearing to the PJCIS in March 2018, Australia's spy chief Duncan Lewis emphasized how strengthened legislative regimes and prosecutions of foreign interference activities would provide strong deterrence against both Australian individuals and foreign entities. ${ }^{51}$ 
Part of the backlash in Australia has also involved broader suspicion of the ethnic Chinese communities in Australia, and a common assumption that any ethnic Chinese actors are likely to be acting on behalf of the Chinese government. At the same time, most of the top political actors implicated in accepting Beijing's carrots have been non-Chinese Australians.

Some voices in Australia have expressed concerns over broad racism and suspicion of the Chinese-Australian community as part of an unproductive policy and political response. ${ }^{52}$ Public debate has been so polarized that Chinese-Australians or those who espouse a more moderate view are often labeled as "CCP stooges." ${ }^{53}$ Far right political parties in Australia have seized on the furor to promote a white nationalistic agenda, painting Chinese investment as an imperialistic strategy to acquire Australian wealth and sovereignty. ${ }^{54}$

Certainly, individuals from Mainland China can be susceptible to being coopted into Beijing's political agenda — for example, through economic incentives or psychological pressure. They can also more effectively serve as intermediaries between the Chinese embassy and Australian politicians. As seen in the recent scandals, Chinese individuals can be important sources of political donations. The revelation of certain individuals as CCP proxies has also been caught up in a broader debate over the role of the Chinese government in controlling-through local United Front organizations-Chineselanguage media, Chinese students, and Chinese-Australian community organizations in Australia. ${ }^{55}$ Many Chinese community associations have been stacked with individuals associated with the Chinese embassy and other United Front organizations, and have been mobilized to become more politically active.

Yet there are also major cleavages within the Chinese diaspora community, particularly between recent migrants from Mainland China and those who have been living in Australia for several generations (and who may also hail from places other than Mainland China). Ethnic Chinese politicians have become more cautious in their political and social activities, for fear of being associated with the CCP. ${ }^{56}$ In addition, many Chinese-Australians participate in United Front-linked community organizations as a pragmatic way of getting business and social connections rather than because of an explicit ideological motivation to serve CCP interests. ${ }^{57}$ There have been reports from the Chinese-Australian community over unhappiness that societal discussion has not "put a face" on individuals, alongside increased feelings of marginalization, pushing some to more actively seek out the Chinese embassy's embrace. ${ }^{58}$

\section{THE CHINA FACTOR: AUTHORITARIAN STATE CAPITALISM}

The nature of the political backlash in Australia highlights the reputation deficits of Chinese capital as well as the challenges China continues to face in other countries. Beijing's attempts to exploit weak campaign finance laws and channel political donations via CCP-linked individuals backfired significantly. Not only did implicated Australian politicians suffer political costs for making statements favorable toward the Chinese government's foreign policy interests, but any activities related to Chinese capital are now regarded as being under a deeper cloud of suspicion. 
In 2018, the Australian government issued a ban on $5 \mathrm{G}$ technology from Huawei and ZTE, two major Chinese companies, over potential espionage concerns. ${ }^{59} \mathrm{~A}$ bid by a leading Hong Kong infrastructure company, Cheung Kong Infrastructure Holdings, CKI, to buy APA Group, a key Australian gas pipeline operator, was blocked on national security grounds. ${ }^{60}$

In addition, Canberra has become far more concerned over inflows of Chinese capital into the South Pacific. The Australian government launched a fund of over US $\$ 2$ billion in infrastructure loans and grants to counter China's economic activities in the South Pacific. ${ }^{61}$ While the Solomon Islands government had signed a deal with Huawei in 2016 to lay an undersea internet cable, Canberra jumped in offering to cover construction costs for the Solomon Islands as well as Papua New Guinea. ${ }^{62}$ Australia also outbid China to fund a military base in Fiji. ${ }^{63}$

Policy responses to China's political financing activities have been framed under a narrative of a generational struggle to protect Australian democracy against the rise of authoritarian governments such as China. Andrew Hastie, an Australian legislator and the chair of the Parliamentary Joint Committee on Intelligence and Security, described China as "a state that uses the whole of society to advance its national objectives. We are less organised because we believe in individual liberty. That's a good thing for Australia but it does make us vulnerable to authoritarian states." ${ }^{64}$

This suggests that backlash against Chinese capital and perceived Chinese political interference is also exacerbated by China's image as an authoritarian regime operating under a model of state-led capitalism. Beijing's attempts to cultivate support from Chinese diaspora communities has further contributed to this perception. Top Chinese leaders have publicly called for overseas Chinese to unite in support of the "China dream," 65 and the Chinese government has encouraged foreign citizens with Chinese heritage to apply for special residency visas. ${ }^{66}$ While research in this special issue (e. g. Ye, this issue) and elsewhere has shown that China's overseas economic activities and foreign policy initiatives are often a reflection of diverging domestic actors and interests (He 2019; Wong 2018; Ye 2019), the opaque nature of the CCP regime and the difficulty in separating commercial from strategic actors leads to assumptions that most activities have the state's hand in them.

PERSUADING AUSTRALIA: BUFFERING EFFECTS OF ECONOMIC INTERDEPENDENCE

Even as there has been political pushback in Australia against China's perceived growing influence, continued economic interdependence and engagement with domestic constituencies have traditionally served as a buffering force. The policy debate is often polarized between the national security community (such as the defense and intelligence establishments) and other societal actors more concerned with broader economic benefits. Certain domestic groups benefiting from a strong Australia-China economic relationship tend to advocate for peaceful and cooperative relations with Beijing. Despite the backlash over PRC-linked political donations, Chinese investment largely remains welcome, and Australia has sought to maintain a cooperative relationship with China. At the same time, Beijing's recent turn to economic coercion has highlighted to Canberra in stark terms the vulnerabilities of interdependence, ultimately 
limiting the buffering sway of Chinese capital and undermining China's influence in Australia.

THE BACKDROP OF ECONOMIC INTERDEPENDENCE AND THE RISE OF CHINESE CAPITAL

China's economic and military rise, coupled with the significant expansion of ChinaAustralia economic ties, has sparked a debate as to Canberra's optimal foreign policy strategy toward Beijing. ${ }^{67}$ Some suggest that a recalibration might be necessary to avoid getting caught up in great power competition. Assuming China's increasing economic, political, and military prominence, particularly in the Asia-Pacific, the costs of confrontation are likely to be much greater for Australia than accommodation of China's power and a move away from US primacy (White 2011).

Indeed, being dragged into a US-led conflict with China would be significantly detrimental for Australia's economy and its relationship with Beijing. The ChAFTA, which came into force at the end of 2015 , is set to bring about considerable tariff reductions across multiple sectors, including major commodities, manufacturing, and services exports. ${ }^{68}$ Economic ties with China have expanded much more rapidly than those with other countries. In June 2019, China constituted a new record of 40 percent of Australia's monthly exports. ${ }^{69}$ In 2018 , bilateral goods trade exceeded US\$125 billion, with Australia as a dominant supplier of China's iron ore and coal. Australian wine and dairy exports grew 18 percent and 34 percent respectively between 2017 and $2018 .{ }^{70}$

China accounts for a small but rapidly growing proportion of foreign investment in Australia. While the United States and United Kingdom remain the largest investors in Australia, together adding up to over 40 percent of total investment at the end of 2017, Chinese investment remains in the single percentage digits. However, Chinese investment has grown significantly over the past decade. Investment from Mainland China, currently ranked as the ninth-largest investor ( 2 percent of total investment), grew 21.6 percent between 2012 and 2017, and accounted for almost 25 percent of all proposed investment in 2016-2017. ${ }^{71}$

Chinese-owned companies accounted for just over $\mathrm{A} \$ 40.4$ billion of direct investment in the four-year period of 2014 to $2017 .{ }^{72}$ Mining and real estate were the largest destinations, although the real estate sector saw the largest number of projects, mostly in commercial real estate. Chinese investments have tended to involve large projects, with state-owned enterprises as an important driving force. Some 87 percent of the total value of Chinese investments came from projects worth more than $\mathrm{A} \$ 100$ million. In addition, state-owned enterprises accounted for 15 percent of projects but 47 percent of the total investment value. ${ }^{73}$

Chinese foreign direct investment (FDI) has slowed in recent years, declining by 40 percent between 2016 and 2017. ${ }^{74}$ This stemmed partly from Beijing's tighter control over capital outflows and broader attempts to regulate foreign investment, as well as growing investor wariness over bilateral ties. According to a KPMG and University of Sydney report, only 35 percent of Chinese firms surveyed said they felt welcome to invest in Australia, down from 52 percent in 2014. Some 70 percent of respondents said that political tensions had made them more cautious about investing in Australia. ${ }^{75}$ Nonetheless, there remains a mood of cautious optimism. Chinese investment in Australia remained relatively robust compared with Chinese investment in other countries. ${ }^{76}$ 
The services sector has also become an important part of the bilateral economic relationship. From 2017 to 2018, Australia's services exports to China expanded by 17.2 percent to over US $\$ 11$ billion. ${ }^{77}$ Tourism and education have become major sources of revenue for Australia's economy, and constitute the country's third largest exports (after iron ore and coal). ${ }^{78}$ In 2018, China became the top source of tourists for Australia, accounting for almost 1.5 million tourist arrivals out of a total of 9.3 million in 2018, or an annual increase of 14.5 percent since $2013 .{ }^{79}$ Spending by Chinese tourists also exceed the average figure per visitor. ${ }^{80}$ In addition, international education contributed around US\$21.7 billion to Australia's economy in 2017. Many Australian universities are now dependent on Chinese students as a major source of revenue. The number of Chinese students increased by 340 percent between 2007 and 2017. ${ }^{81}$ Around one-third of foreign students in Australia are from Mainland China, constituting 125,000 students in 2018, with 60 percent at the leading Group of Eight universities in Australia. ${ }^{82}$

Overall, Australia's growing depth of economic interdependence with China, and the accompanying immediate benefits, has both strengthened perceptions and bolstered arguments of close political and economic ties with Beijing as an important part of Australia's national interests. ${ }^{83}$ As will be discussed below, a number of key domestic constituencies in Australia have actively articulated such views in an effort to maintain a cooperative foreign policy toward China.

\section{CULTIVATING DOMESTIC CONSTITUENCIES}

In Australia, there remain considerable divisions among societal groups on their levels of support for Chinese capital. Surveys have found that Chinese investors view Australian business leaders, state governments, and local councils as highly supportive compared with other actors such as the federal government, the Foreign Investment Review Board (FIRB), and the media. ${ }^{84}$ Many of these divisions stem from perceptions of, and actual gains in, economic benefits from China.

Unsurprisingly, business actors have a strong interest in non-provocative foreign policies toward Beijing (see also Carr 2014, 182, 254). They have often criticized government policy for being too harsh toward China. For example, the business community slammed the government's espionage and foreign interference legislation as endangering economic and political ties with Beijing. ${ }^{85}$ The Australia China Business Council, representing major corporations doing business with China, expressed concern in a written submission to parliament over the government's "disproportionate response" and the fostering of an "atmosphere of suspicion. Mining magnate Andrew Forrest also called for a stop to the ongoing debate that "fuels distrust, paranoia and a loss of respect." 86

Observers note a permeation in the business community about being grateful to China, including Australian businessman James Packer's previous comment that Australia should express "gratitude" to China. ${ }^{87}$ In private meetings with the government, major company executives expressed fears that Beijing would impose retaliatory tariffs. ${ }^{88}$ Australian winemakers facing delays at Chinese customs quickly lobbied for Canberra to resolve political tensions with Beijing. ${ }^{89}$ A range of business actors, such as the head of a mining firm and a former senior politician who is now president of the Australia China Business Council, have also called for Canberra to be more supportive of China's 
BRI, an ambitious plan to promote Chinese investment and infrastructure projects across a range of countries. ${ }^{90}$

In addition, the higher education sector has been a vocal advocate of maintaining positive relations with Beijing. University leaders have criticized the government's tough response over CCP influence as "Sinophobic" and unwarranted. There have been a number of incidents in which universities have canceled events relating to contentious issues such as Tibet or overseas dissidents, or when Mainland Chinese students and on-campus organizations (the Chinese Students and Scholars Association) have vocally protested individual lecturer statements or actions that they perceived to undermine PRC interests, leading to university apologies. ${ }^{91}$ Universities Australia, a coalition body, sent a delegation of vice-chancellors to Beijing in April 2018 in an effort to reassure China and forestall any cut-off of Chinese student enrollment. ${ }^{92}$

State governments have also been active in promoting closer economic cooperation and implementing policies to attract Chinese capital. This has carried on despite apparent diplomatic tensions between Australia and China. For example, in late 2018, New South Wales (which is apparently the largest state recipient of PRC investment) signed a Memorandum of Understanding (MoU) with a major Chinese airline to boost tourism..$^{93}$ Even more contentiously, the state government of Victoria signed an $\mathrm{MoU}$ on China's BRI, to the surprise of the federal government. ${ }^{94}$ This went against Canberra's previous decision not to formally sign onto the initiative due to strategic concerns, although it had signed a MoU on cooperating with BRI projects in third countries. ${ }^{95}$ While the MoU is not a legally binding agreement, its political symbolism points to strong elite interest in the economic opportunities provided by Chinese capital.

\section{A BALANCING ACT}

While Canberra's tough rhetorical and legal response to China's political financing activities points to the limitations of such an approach for gaining influence, Australia has by and large perceived closer economic and political ties with China to be in its national interest, although Beijing's coercive turn in 2020 has reduced support for a cooperative policy approach. This balancing act is reflected in both government policies as well as public attitudes.

Prior to 2020, Canberra continued efforts to keep bilateral ties on a positive track. The foreign minister stated publicly that Australia does not see China "as posing a military threat to Australia," distancing the Australian government from the US National Security Strategy released in January $2018 .{ }^{96}$ Before he was ousted in a party leadership challenge, Australian Prime Minister Malcolm Turnbull had announced his intention to visit Beijing to repair trade relations, particularly as Australian businesses complained of unusual Chinese customs delays. ${ }^{97}$ The following administration, under Scott Morrison, announced a new US\$31.5 million foundation, the National Foundation for AustraliaChina Relations, to promote closer economic and cultural cooperation, and appointed a top China specialist as Australia's next ambassador to Beijing.98

Public attitudes remain mixed regarding China. While both 2017 and 2018 polls by the Lowy Institute measured public "feelings" toward China at 58 degrees (out of 100), by 2019 they had cooled down to 40 degrees. ${ }^{99}$ Some 52 percent of respondents in 2018, but only 32 percent in 2019 trusted China to act responsibly in the world. In 2018, 82 percent 
viewed China as "more of an economic partner than a military threat," an increase of three points from 2017, and a majority of respondents regarded China as the world's leading economic power.

While this suggests an understanding of the importance of economic interdependence with China, it also comes with wariness of Chinese capital as a source of interference in Australia's domestic politics. Some 63 percent of respondents in 2018 were concerned about China's foreign influence in Australia's political processes, and 41 percent believed foreign interference in Australian politics was a critical threat to national security ( 89 percent of respondents believed that foreign interference was either a critical or important national security threat). In 2019, this had increased to 49 percent of respondents thinking that foreign interference was a critical national security threat (with 93 percent saying it was either a critical or important threat). Some 44 percent felt that when considering which foreign companies should be allowed to supply new technology for important services in Australia, the government's first priority should be to protect Australians from foreign intrusion, ahead of bringing in the most advanced technology or keeping prices down, suggesting broad support for the government's decision to ban Huawei from building $5 \mathrm{G}$ networks.

We also see growing suspicion of Chinese capital and its geopolitical ramifications. Some 72 percent of respondents in 2018 and 68 percent in 2019 thought that the Australian government was allowing too much investment from China, an increase from merely 56 percent in 2014. In 2019, 79 percent agreed that China's infrastructure investment projects across Asia were part of China's plans for regional domination, 52 percent disagreed that these projects were good for the region, 74 percent felt that Australia was too economically dependent on China, and 73 percent agreed that Australia should try to prevent China from increasing its influence in the Pacific. Some 77 percent-an increase from 66 percent in 2015-felt that Australia should do more to resist China's military activities in its region, even if this affected the economic relationship.

While the Australian public has been more skeptical of foreign investors in general, not just against China but also against Japan and the United States, ${ }^{100}$ and some have argued that the share of foreign ownership matters more than the investor country (Laurenceson et al. 2018), the public opinion data discussed above point to growing concerns over the role of Chinese capital, not just within Australia but also in the Asia-Pacific region more broadly. Suspicion of infrastructure projects elsewhere underline the longer-term spillover reputational costs of non-transparent approaches to economic statecraft, including the association of Chinese capital with Beijing's foreign interference and influence activities.

Moreover, Beijing's shift in the second half of 2020 to more overtly aggressive tactics of economic coercion and political pressure has only served to worsen public and elite perceptions of China. These tactics have underscored longstanding fears that the Australian economy is vulnerable to Chinese government coercion, while empowering domestic constituencies skeptical of Chinese capital and cooperative ties with Beijing.

This is not the first time China has imposed trade restrictions on Australian goods. In 2019, Australian coal, beef, and wine exports were held up at Chinese ports, under the guise of custom inspections but alleged by some as a political move, ${ }^{101}$ pointing to the latent leverage provided by economic linkages with China. But political retaliation by the Chinese government, such as canceling leader visits, had remained a more likely 
outcome. ${ }^{102}$ Large-scale economic coercion would also be costly for China itself. The Chinese economy is arguably dependent on Australia's position as a supplier of raw materials. ${ }^{103}$ The demand-driven nature of Mainland Chinese students in Australia means it is not as easy for Beijing to turn off the tap, and PRC airline companies have also been major beneficiaries of expanded tourist routes between China and Australia. ${ }^{104}$

Nonetheless, in 2020 Beijing escalated its economic coercion of Australia through trade bans and tariffs on a wide range of sectors, from coal and timber to wine, seafood, and barley. This occurred in the wake of official Australian statements criticizing policies in Taiwan, and Hong Kong, and human rights (particularly in Xinjiang), as well as the government's call for an independent inquiry into the origins of the coronavirus pandemic. ${ }^{105}$ In particular, the Chinese embassy in Canberra issued a list of 14 demands that went beyond China's traditional "core interests" in foreign policy to include issues of academic research, media reporting, and political discourse in Australia. ${ }^{106}$

The soured bilateral relationship points to how economic coercion could backfire by making political elites and commercial actors more wary of the costs of doing business with China. In response, Canberra has dug in its heels, continued to scrutinize incoming Chinese investments for national security risks, and proposed a new law (seen as targeting China) that would allow the federal government to cancel state and university deals with foreign governments. ${ }^{107}$ The renewed turn to coercion has arguably validated concerns about overdependence on the Chinese economy, worsened public and elite attitudes toward China, and further shrunk the limited policy gains that Beijing has sought in Australia. Beijing's removal of the velvet gloves also sends a strong negative signal to other countries and alters international perceptions of China. ${ }^{108}$ Coercion thus undermines the buffering effects of economic interdependence and amplifies concerns over the nature of Chinese capital and Chinese economic influence.

\section{CONCLUSION}

Overall, there remain divisions in Australia about how to manage the economic benefits alongside the political risks in its relationship with China. First, the use of economic inducements linked to the Chinese government for political purposes has led to significant backlash in Australia. Attempts to use political donations from CCPlinked individuals, particularly in less-than-transparent ways that seek to intervene in democratic political processes and coopt elites, have been linked to perceptions of foreign interference in Australia's democratic processes. Canberra pushed forward with a tough rhetorical and legal response to China's attempts at economic statecraft, despite protestations from some quarters.

The backlash has also created reputational costs for Chinese capital, with longer-term negative implications for China's overseas image. It has certainly reinforced the "reputational deficits" often faced by Chinese capital (e.g. Shi and Seim 2021); these conflicts often stem from gaps between how China operates versus local norms and institutions in recipient countries (Wong 2019). Additionally, Chinese capital is facing greater political scrutiny overall, exacerbated by common assumptions that all economic activities have the hand of the party-state behind them. The political impacts of outbound Chinese investment are often mediated and worsened by widespread perceptions of cohesive state control over capital, despite often fragmented policy implementation as seen in 
China's much-discussed BRI (Ye, this issue). This points to the challenges faced by Chinese capital despite the broader context of economic interdependence and engagement.

At the same time, economic interdependence has arguably created a buffer against political tensions through the long-term empowerment of Australian domestic actors with vested interests in positive ties with Beijing. We have seen significant domestic coalitions lobbying for more cooperative policies toward China, and exerting policy pressure on Canberra. In Australia, the most vocal China advocates are in fact certain local and national politicians as well as major business actors who either have received direct economic benefits from China or have vested economic interests. The allure of economic benefits has undoubtedly induced a perception in Canberra that negative political ties with Beijing are not in its national interest, causing political (and certainly business) leaders to engage in a delicate dance to avoid "angering" China unnecessarily.

Nonetheless, findings from the Australia case suggest that continued wariness of Chinese capital as being directed by the CCP, combined with existing reputational costs from the use of non-transparent carrots, will pose challenges for the reputation of China's outbound capital as well as for Beijing's ability to use economic statecraft for political influence. Although Chinese investments may benefit the recipient country more broadly, concerns and criticisms can still arise when the presence of Chinese capital is seen as potentially undermining national security and sovereignty, or acting through illegitimate channels. Additionally, renewed economic coercion by Beijing further raises the costs of accepting inducements and undermines the lure of Chinese capital.

More broadly, the Australia case underlines the dilemmas faced by developed democracies in accepting Chinese capital and managing economic and political ties with Beijing. The ways in which China uses its economic capabilities when interacting with liberal democracies are an increasingly salient topic of concern. Many developed countries such as the United States and various European nations are starting to grapple with the implications of China's economic inducements, particularly as Beijing continues to expand its BRI. Democratic processes and institutions promote resilience and pushback, but their very openness and inclusiveness can also provide avenues for foreign countries such as China to exercise influence through economic statecraft. The political access afforded to donors and individuals covertly linked to the CCP (or any other foreign government), even if the strings have not yet been pulled for a specific policy change, can pose a latent concern for national security. ${ }^{109}$ As Verbal Klint said about the mysterious Keyser Soze in the movie The Usual Suspects, "The greatest trick the Devil ever pulled was convincing the world he didn't exist." 110

Audrye Wong is an Assistant Professor of Political Science and International Relations at the University of Southern California. She was previously a Grand Strategy, Security, and Statecraft Postdoctoral Fellow at the Harvard Kennedy School and MIT's Security Studies Program. She received a PhD in Security Studies from Princeton University's School of Public and International Affairs, where she was a National Science Foundation Graduate Research Fellow.

ACKNOWLEDGMENTS

For helpful comments on earlier versions, I thank Meir Alkon, Tom Christensen, Avery Goldstein, John Ikenberry, John Ravenhill, Weiyi Shi, Rory Truex, Jack Zhang, 
participants at the special issue workshop organized by Min Ye at the Boston University Pardee School GDP Center, and Steph Haggard and the anonymous reviewers at JEAS.

\section{CONFLICT OF INTEREST}

The authors declare no conflicts of interest.

\section{NOTES}

1. Nick McKenzie, Chris Uhlmann, Richard Baker, Daniel Flitton, and Sashka Koloff, "China's Operation Australia: Payments, Power and Our Politicians," Sydney Morning Herald, June 6, 2017.

2. Interview, Nick McKenzie, journalist, Melbourne, March 16, 2018.

3. Interview, Tim Watts, Labor Party MP, Melbourne, March 15, 2018.

4. Primrose Riordan, "China's Local Emperor Huang Xiangmo Says Politics Just Like Sport," Australian Financial Review, September 1, 2016.

5. Nick McKenzie and Sarah Ferguson, "Power and Influence: The Hard Edge of China's Soft Power," Four Corners, ABC TV, June 5, 2017.

6. McKenzie and Ferguson, "Power and Influence."

7. "Dastyari Caught Defying Labor on China," Sky News, November 29, 2017.

8. Nick McKenzie, James Massola, and Richard Baker, "Sam Dastyari Warned Big Chinese Donor to Go Outside, His Phone was Bugged," Sydney Morning Herald, November 29, 2017.

9. McKenzie and Ferguson, "Power and Influence."

10. Interview, Nick McKenzie, journalist, Melbourne, March 16, 2018.

11. Christopher Knaus and Tom Phillips, "Turnbull Says Australia will 'Stand Up' to China as Foreign Influence Row Heats Up," Guardian, December 8, 2017.

12. Nick O'Malley, Philip Wen, and Michael Koziol, "Donations, Dastyari and Chinese Soft Power," Sydney Morning Herald, September 9, 2017.

13. Damien Cave and Jacqueline Williams, "Australian Politics is Open to Foreign Cash, and China has Much to Gain," New York Times, June 6, 2017.

14. Sarah Martin, "Bob Carr's Think Tank 'Operating as a China Propaganda Arm', The Australian, September 9, 2016.

15. Matthew Knott and Heath Aston, "Don't Become 'Propaganda Vehicles' for China: Universities Warned Over Donations," Sydney Morning Herald, September 8, 2016; James Leibold, "The AustraliaChina Relations Institute Doesn't Belong at UTS," The Conversation, June 4, 2017; John Fitzgerald, "Business as Usual: Accommodating China's Interests in Australia," The Australian, September 9, 2016.

16. Interview, Bob Carr, Sydney, March 13, 2018.

17. Interview, Peter Jennings, executive director of the Australian Strategic Policy Institute and former senior government official, Canberra, March 7, 2018.

18. Interview, Primrose Riordan, Australian journalist, Canberra, March 8, 2018.

19. Interview, Australian journalist, Melbourne, March 16, 2018.

20. Interviews, Canberra and Melbourne, March 2018.

21. Clive Hamilton and Alex Joske, "Political Networking the Chinese Way - a Sydney MP and His 'Community Adviser',' Sydney Morning Herald, June 22, 2017.

22. Interview, Richard Rigby, retired diplomat and former consul-general in Shanghai, Canberra, March 7, 2018.

23. Andrew Bolt, "Dastyari, Carr: Took China's Cash, Took China's Side," Herald Sun, September 7, 2016.

24. Paul Karp and agencies, "Sam Dastyari Told Tanya Plibersek Not to Meet a Hong Kong Democracy Activist - Report," Guardian, December 10, 2017.

25. John Fitzgerald, "Australia," Asan Special Forum on China's Sharp Power and Foreign Interference, April 24, 2018.

26. Interview, Richard Rigby, retired diplomat and former consul general in Shanghai, Canberra, March 7, 2018.

27. Interviews in Canberra and Melbourne, March 2018. 
28. Interviews with Primrose Riordan, Australian journalist, Canberra, March 8, 2018; Nick McKenzie, Australian journalist, Melbourne, March 16, 2018.

29. Peter Dixon and Maureen Rimmer, "Free Trade Agreement: What's Really at Stake if China Deal Falls Through?” The Conversation, September 7, 2015.

30. See, for example, Nick McKenzie, Sashka Koloff and Mary Fallon, "Tony Abbott Attended Re-election Fundraiser at Fugitive Chinese Tycoon's Golf Club,” ABC, April 5, 2019.

31. Interview, Allan Gyngell, former director-general of the Australian Office of National Assessments, Canberra, March 9, 2018; Tim Watts, Labor Party MP for Gellibrand, Melbourne, March 15, 2018.

32. Peter Hartcher, "Riding the Red Dragon Express Not a Good Look," Sydney Morning Herald, September 3, 2016; Editorial, "China's Influence-Peddling in Australia," Wall Street Journal, September 14, 2016; "Sam Dastyari-linked Political Donor Resigns from Bob Carr Institute After Major Review," Australian Financial Review, September 21, 2016.

33. For a helpful overview, see Kelsey Munro, “A Free Press is a Magic Weapon Against China's Influence Peddling," Lowy Interpreter, December 18, 2017.

34. Chris Uhlmann and Andrew Greene, "Chinese Donors to Australian Political Parties: Who Gave How Much?" Australian Broadcasting Corporation, August 21, 2016.

35. See, for example, John Garnaut, "How China Interferes in Australia and How Democracies Can Push Back," Foreign Affairs, March 9, 2018; Peter Jennings, "At Last, We're Awake to China's Predatory Meddling," The Weekend Australian, December 16, 2017; McKenzie and Ferguson, "Power and Influence"; "An Open Letter from Concerned Scholars of China and the Chinese Diaspora," Policy Forum, March 19, 2018; Fergus Hunter, "Leading China Scholars Sign Open Letter Saying Beijing Influence Debate is Not Racist," Sydney Morning Herald, March 27, 2018.

36. See, for example, John Fitzgerald, "China Influence: In Defence of Parliamentary Sovereignty," Lowy Interpreter, April 19, 2018.

37. McKenzie and Ferguson, "Power and Influence."

38. See, for example, Primrose Riordan, "Robb Under Fire for China Policy Push," Australian Financial Review, November 1, 2016; Amy Remeikis, "Sam Dastyari Quits as Labor Senator Over China Connections," Guardian, December 11, 2017.

39. Jacqueline Williams, “Australian Lawmaker Quits Amid Questions Over China Ties," New York Times, December 12, 2017; Remeikis, "Sam Dastyari Quits."

40. Primrose Riordan, "MP Severs Ties with Chinese Billionaire," The Australian, December 1, 2017.

41. Interview, Tim Watts, Labor Party MP for Gellibrand, Melbourne, March 15, 2018.

42. Interview, James Laurenceson, Deputy Director at ACRI, Sydney, March 12, 2018.

43. Knaus and Phillips, "Turnbull Says Australia will 'Stand up'."

44. John Garnaut, "How China Interferes in Australia and How Democracies Can Push Back," Foreign Affairs, March 9, 2018; "Australia to Ban Covert Foreign Interference in Politics," Associated Press, June 27, 2018.

45. "Protecting Australian from Foreign Interference: Media Release," Prime Minister, Attorney-General, Minister of Finance, December 5, 2017, www.pm.gov.au/media/protecting-australia-foreign-interference; Henry Belot, "Explainer: Here's What You Need to Know About the Government's Foreign Interference Laws," ABC, February 7, 2018.

46. See Review of the National Security Legislation Amendment (Espionage and Foreign Interference) Bill 2017, www.aph.gov.au/Parliamentary_Business/Committees/Joint/Intelligence_and_Security/EspionageFInterference; David Wroe, "Freedom of Press Concerns Prompt Changes to Foreign Interference Laws," Sydney Morning Herald, March 5, 2018.

47. "Australia to Ban Covert Foreign Interference."

48. Yee-Fui Ng, "The Foreign Donations Bill will Soon be Law: What will It Do, and Why is It Needed?," The Conversation, November 27, 2018, http://theconversation.com/the-foreign-donations-bill-will-soon-belaw-what-will-it-do-and-why-is-it-needed-107095.

49. Interviews with senior diplomat working on Asia-Pacific issues at Department of Foreign Affairs and Trade, Canberra, March 8, 2018; Allan Gyngell, former director-general of the Australian Office of National Assessments, Canberra, March 9, 2018.

50. Interview, John Garnaut, former journalist and member of Prime Minister's Office, March 14, 2018; John Garnaut, "How China Interferes in Australia and How Democracies Can Push Back," Foreign Affairs, March 9, 2018; Fitzgerald, "Australia." 
51. National Security Legislation Amendment (Espionage and Foreign Interference) Bill 2017, Parliamentary Joint Committee on Intelligence and Security, Melbourne, March 16, 2018.

52. David Brophy, "David Brophy reviews Silent Invasion: China's Influence in Australia by Clive Hamilton," Australian Book Review, March 21, 2018; "An Open Letter from Concerned Scholars of China and the Chinese Diaspora," Policy Forum, March 19, 2018.

53. Jieh-Yung Lo, "Just Because I have a Moderate View on China Doesn't Make me a Beijing Stooge," The Guardian, April 5, 2018.

54. See, for example, John Hood AC, "China's One Belt One Road Imperialist Designs upon Australia: Traitor Class in Darwin Grab Their Yuan Cut," media release, Australia First Party, July 10, 2018, https://australiafirstparty.net/chinas-one-belt-one-road-imperialist-designs-upon-australia-traitor-class-indarwin-grab-their-yuan-cut.

55. Clive Hamilton and Alex Joske, "Submission to the Parliamentary Joint Committee on Intelligence and Security: United Front Activities in Australia," February 2018.

56. Damien Cave, "Espionage Bills in Australia Stir Fears of Anti-Chinese Backlash," New York Times, December 19, 2017.

57. Interview, Tim Watts, Labor Party MP for Gellibrand, Melbourne, March 15, 2018.

58. Interviews with Richard Rigby, retired diplomat and former consul general in Shanghai, Canberra, March 7, 2018; Heidi Han, journalist, Sydney, March 13, 2018.

59. "Huawei and ZTE Handed 5G Network Ban in Australia," BBC, August 23, 2018; Saheli Roy Choudhury, "Former Australian PM Turnbull Explains Why His Government Banned Huawei, ZTE from Selling 5G Equipment," CNBC, March 28, 2019.

60. Simon Segal, "Blocking Chinese Gas Takeover Won't Damage Australia's Foreign Investment Pipeline," The Conversation, November 22, 2018.

61. "China Shuns Rivalry in Pacific as Australia Says 'This is Our Patch," Reuters, November 7, 2018.

62. Liam Fox, "Australia, Solomon Islands, PNG Sign Undersea Cable Deal Amid Criticism from China," ABC, July 11, 2018.

63. Christopher Mudaliar, "Australia Outbids China to Fund Fiji Military Base," Lowy Interpreter, October 4, 2018.

64. David Wroe, "Defending Democracy a Generational Struggle, Australian MPs Warn," Sydney Morning Herald, July 10, 2018.

65. See, for example, Timothy Heath, "Beijing's Influence Operations Target Chinese Diaspora," War on the Rocks, March 1, 2018.

66. Jieh-Yung Lo, "Beijing's Welcome Mat for Overseas Chinese," The Lowy Interpreter, March 6, 2018.

67. See, for example, Daniel Flitton, "The Great China Debate: Clive Hamilton v Hugh White," The Interpreter, Lowy Institute, March 7, 2019, www.lowyinstitute.org/the-interpreter/great-china-debate-clive-hamilton-v-hugh-white.

68. See, for example, "ChAFTA Outcomes at a Glance," Australian Government Department of Foreign Affairs and Trade, www.dfat.gov.au/trade/agreements/in-force/chafta/fact-sheets/Pages/chafta-outcomes-at-aglance.aspx.

69. David Uren, "Australia's Booming Trade with China will Shape Strategic Policy," The Strategist, Australian Strategic Policy Institute, September 3, 2019, www.aspistrategist.org.au/australias-booming-trade-withchina-will-shape-strategic-policy.

70. Peter Drysdale, "Getting the Australia-China Relationship Right," East Asia Forum, May 23, 2019, www.eastasiaforum.org/2019/05/23/getting-the-australia-china-relationship-right.

71. "Foreign Investment Statistics," Department of Foreign Affairs and Trade, https://dfat.gov.au/trade/ resources/investment-statistics/Pages/statistics-on-who-invests-in-australia.aspx. Data include direct, portfolio, and other investments. As a comparison, the United States and United Kingdom remain the largest investors in Australia, together adding up to over 40 percent of total investment at the end of 2017.

72. Chinese Investment in Australia (CHIIA) Database, East Asian Bureau of Economic Research, Crawford School of Public Policy, Australian National University, 2018, www.chiia.eaber.org. Chinese investments include those by subsidiaries effectively controlled by a Mainland Chinese investor.

73. Greg Jericho, "Following the Money: Where China's \$40bn Investment in Australia is Going," The Guardian, October 8, 2018; Susan Travis, The Story of Chinese Direct Investment in Australia (2014-2017), EABER Working Paper Series No. 133, October 2018. 


\section{Audrye Wong}

74. Greg Jericho, "Following the Money"; Michael Heath, "Chinese Investors Grow Wary of Australia as Tensions Rise," Bloomberg, June 12, 2018.

75. Hans Hendrischke and Wei Li, "Chinese Investment in Australia Falls as Political Debate Hits Confidence," The Conversation, June 12, 2018, https://theconversation.com/chinese-investment-in-australia-falls-aspolitical-debate-hits-confidence-98144.

76. "Demystifying Chinese Investment in Australia: June 2018," KPMG, June 12, 2018, https://home. kpmg/au/en/home/insights/2018/06/demystifying-chinese-investment-in-australia-june-2018.html.

77. Drysdale, "Getting the Australia-China relationship right."

78. "Chinese Tourists to Australia Slow but Record Americans Head Down Under," Reuters, September 11, 2019, www.reuters.com/article/us-australia-economy-tourism/chinese-tourists-to-australia-slow-but-recordamericans-head-down-under-idUSKCN1VW0OZ.

79. Jason Karaian, "More Tourists in Australia Now Come from China Than New Zealand," Quartz, April 21, 2018, https://qz.com/1258898/chinese-tourists-in-australia-now-outnumber-visitors-from-new-zealand; Edmund Tang, "Australia's Tourist Arrivals Exceed 9 million in 2018," Australian Trade and Investment Commission, February 27, 2019, www.austrade.gov.au/news/economic-analysis/australias-tourist-arrivalsexceed-9-million-in-2018.

80. Philippe Karam and Dirk Muir, Australia's Linkages with China: Prospects and Ramifications of China's Economic Transition, IMF Working Paper, May 2018.

81. Karam and Muir, Australia's Linkages with China.

82. Jordan Baker, “A Knowledge Race': Australian Universities Set to Suffer Drop in Students from China," Sydney Morning Herald, March 1, 2019, www.smh.com.au/education/a-knowledge-race-australianuniversities-set-to-suffer-drop-in-students-from-china-20190301-p5113e.html.

83. Neil Irwin, "Australia and the US are Old Allies: China's Rise Changes the Equation," New York Times, May 11, 2019, www.nytimes.com/2019/05/11/upshot/australia-relationship-china-us-trade.html.

84. Hans Hendrischke and Wei Li, "Chinese Investment in Australia Falls as Political Debate Hits Confidence," The Conversation, June 12, 2018, https://theconversation.com/chinese-investment-in-australia-falls-aspolitical-debate-hits-confidence-98144.

85. Glenda Korporaal, "Politicians Endanger China Links," The Australian, March 7, 2018.

86. Glenda Korporaal, "Business Lobby Lashes China Transparency Bill,” The Australian, March 6, 2018; Korporaal, "Politicians Endanger China Links."

87. Interview, Richard McGregor, Australian journalist and senior fellow at the Lowy Institute, Sydney, March 12, 2018.

88. Interview, Australian journalist, Sydney, March 12, 2018.

89. “Australian Winemakers Press Prime Minister to End Rift with China," Reuters, June 6, 2018.

90. David Wroe, “'How Empires Begin': China has Made Its Global Move. This is Australia's Response," Sydney Morning Herald, June 22, 2018.

91. See, for example, John Ross, "Australian Universities' Student Recruitment from China Flatlines," Times Higher Education, March 5, 2018.

92. Ross, "Australian Universities' Student Recruitment from China Flatlines."

93. "NSW Strikes Deal with China Eastern Airlines," ETB Travel News, November 7, 2018, http://australia. etbtravelnews.global/371020/nsw-strikes-deal-with-china-eastern-airlines.

94. Paul Karp, "Scott Morrison Rebukes Victoria for Signing Up to China's Belt and Road Initiative," The Guardian, November 5, 2018.

95. Andrew Greene and Andrew Probyn, “One Belt, One Road: Australian 'Strategic' Concerns Over Beijing's Bid for Global Trade Dominance," ABC, October 22, 2017; David Wroe, "Foreign Affairs Ministry Opts for Secrecy Over China Infrastructure Agreement," Sydney Morning Herald, July 30, 2018.

96. Fergus Hunter, “'We Have a Different Perspective': Julie Bishop Distances Australia from US on China, Russia Threat," Sydney Morning Herald, January 29, 2018, www.smh.com.au/politics/federal/we-have-a-different-perspective-julie-bishop-distances-australia-from-us-on-china-russia-threat-20180129-h0ppym.html.

97. "Australian Prime Minister Malcolm Turnbull to Visit China to Improve Trade Relations," Reuters, May 19, 2018, www.scmp.com/news/china/diplomacy-defence/article/2146877/australian-prime-ministermalcolm-turnbull-visit-china.

98. Ben Packham and Geoff Chambers, "Morrison Puts \$44m into Foundation to Improve China Ties," The Australian, March 28, 2019.

99. Lowy Institute Poll, http://lowyinstitutepoll.lowyinstitute.org. 
100. Interview, Peter Drysdale, professor emeritus and head of the East Asian Bureau of Economic Research, Australian National University, March 6, 2018.

101. Jason Scott, Dan Murtaugh, and Bloomberg, "China Restricts Australian Coal Imports in Likely Retaliation to Huawei 5G Ban," Fortune, February 21, 2019, http://fortune.com/2019/02/21/china-australia-coalimports; Kirsty Needham, "China's Coal Industry Lashes Australia for 'Irresponsible Comments'," Sydney Morning Herald, April 12, 2019.

102. Interview, senior diplomat working on Asia-Pacific issues at Department of Foreign Affairs and Trade, Canberra, March 8, 2018; “China Shunned Australia’s Minister During Recent Visit: Diplomat," Reuters, May 31, 2018.

103. Interview, Peter Drysdale, professor emeritus and head of the East Asian Bureau of Economic Research, Australian National University, March 6, 2018.

104. Interviews, senior diplomat working on Asia-Pacific issues at Department of Foreign Affairs and Trade, Canberra, March 8, 2018; Richard McGregor, Australian journalist and senior fellow at the Lowy Institute, Sydney, March 12, 2018.

105. Gerry Shih, "China Sharply Ramps Up Trade Attacks on Australia Over Political Grievances," The Washington Post, November 27, 2020.

106. Lucas Niewenhuis, "The 14 Sins of Australia: Beijing Expands List of Grievances and Digs in for Extended Diplomatic Dispute," SupChina, November 18, 2020.

107. Jonathan Pearlman, "Aussie Bid to Veto State Deals with Foreign Govts May Hurt China Ties," The Straits Times, August 30, 2020.

108. Interview, Peter Jennings, executive director of the Australian Strategic Policy Institute and former senior-level government official, Canberra, March 7, 2018.

109. Interview, Nick McKenzie, Australian journalist, Melbourne, March 16, 2018.

110. Thanks to Nick McKenzie for suggesting this quote.

\section{REFERENCES}

Abdelal, Rawi, and Jonathan Kirshner. 2000. "Strategy, Economic Relations, and the Definition of National Interests." In Power and the Purse: Economic Statecraft, Interdependence, and National Security, edited by Jean-Marc F. Blanchard, Edward D. Mansfield, and Norrin M. Ripsman, 119-156. London: Frank Cass.

Baldwin, David A. 1971. "The Power of Positive Sanctions." World Politics 24 (1): 19-38.

- 1985. Economic Statecraft. Princeton, NJ: Princeton University Press.

Baldwin, David A., and Robert A. Pape. 1998. "Evaluating Economic Sanctions." International Security 23 (2): 189-198.

Carr, Bob. 2014. Diary of a Foreign Minister. Sydney: UNSW Press.

Copeland, Dale C. 1996. "Economic Interdependence and War: A Theory of Trade Expectations." International Security 20 (4): 5-41.

Davis, Christina L. 2009. "Linkage Diplomacy: Economic and Security Bargaining in the Anglo-Japanese Alliance, 1902-23." International Security 33 (3): 143-179.

Davis, Patricia Annette. 1999. The Art of Economic Persuasion: Positive Incentives and German Economic Diplomacy. Ann Arbor, MI: University of Michigan Press.

Drezner, Daniel W. 1999. The Sanctions Paradox: Economic Statecraft and International Relations. Cambridge: Cambridge University Press.

Flores-Macías, Gustavo A., and Sarah E. Kreps. 2013. "The Foreign Policy Consequences of Trade: China's Commercial Relations with Africa and Latin America, 1992-2006." The Journal of Politics 75 (2): 357-371.

Fuchs, Andreas, and Nils-Hendrik Klann. 2013. "Paying a Visit: The Dalai Lama Effect on International Trade." Journal of International Economics 91 (1): 164-177.

Goh, Evelyn. 2014. "The Modes of China's Influence: Cases from Southeast Asia." Asian Survey 54 (5): $825-\mathrm{s} 848$.

Hamilton, Clive. 2018. Silent Invasion: China's Influence in Australia. Sydney: Hardie Grant Books.

He, Baogang. 2019. "The Domestic Politics of the Belt and Road Initiative and Its Implications." Journal of Contemporary China 28 (116): 180-195. 


\section{4}

Audrye Wong

Hirschman, Albert O. 1945. National Power and the Structure of Foreign Trade. Berkeley, CA: University of California Press.

Kahler, Miles, and Scott L. Kastner. 2006. "Strategic Uses of Economic Interdependence: Engagement Policies on the Korean Peninsula and Across the Taiwan Strait." Journal of Peace Research 43 (5): 523-541.

Kastner, Scott L. 2007. "When do Conflicting Political Relations Affect International Trade?” Journal of Conflict Resolution 51 (4): 664-688.

- 2014. "Buying Influence? Assessing the Political Effects of China's International Trade." Journal of Conflict Resolution 60 (6): 980-1007.

Kirshner, Jonathan. 1997. Currency and Coercion: The Political Economy of International Monetary Power. Princeton, NJ: Princeton University Press.

2002. "Review Essay: Economic Sanctions: The State of the Art." Security Studies 11 (4): 160-179.

Laurenceson, James, Hannah Bretherton, Paul F. Burke, and Edward Wei. 2018. "Chinese Investment in Australian Infrastructure Assets: Accounting for Local Public Preferences.” China Economic Journal 12 (1): 77-92.

Long, William J. 1996. "Trade and Technology Incentives and Bilateral Cooperation.” International Studies Quarterly 40 (1): 77-106.

Mansfield, Edward D., and Brian M. Pollins. 2001. "The Study of Interdependence and Conflict: Recent Advances, Open Questions, and Directions for Future Research.” Journal of Conflict Resolution 45 (6): 834-859.

Mansfield, Edward D., and Brian M. Pollins, eds. 2003. Economic Interdependence and International Conflict: New Perspectives on an Enduring Debate. Ann Arbor, MI: University of Michigan Press.

Mastanduno, Michael. 2000. "Economic Statecraft, Interdependence, and National Security: Agendas for Research." In Power and the Purse: Economic Statecraft, Interdependence, and National Security, edited by Jean-Marc F. Blanchard, Edward D. Mansfield, and Norrin M. Ripsman, 288-316. London: Frank Cass.

Narizny, Kevin. 2007. The Political Economy of Grand Strategy. Ithaca, NY: Cornell University Press.

Newnham, Randall E. 2002. Deutsche Mark Diplomacy: Positive Economic Sanctions in German-Russian Relations. University Park, PA: Pennsylvania State University Press.

Nincic, Miroslav. 2011. The Logic of Positive Engagement. Ithaca, NY: Cornell University Press.

Norris, William J. 2016. Chinese Economic Statecraft: Commercial Actors, Grand Strategy, and State Control. Ithaca, NY: Cornell University Press.

Papayoanou, Paul A. 1999. Power Ties: Economic Interdependence, Balancing, and War. Ann Arbor, MI: University of Michigan Press.

Papayoanou, Paul, and Scott Kastner. 2000. "Sleeping with the (Potential) Enemy: Assessing the US Policy of Engagement with China." In Power and the Purse: Economic Statecraft, Interdependence, and National Security, edited by Jean-Marc F. Blanchard, Edward D. Mansfield, and Norrin M. Ripsman. London: Frank Cass pp. 157-187.

Pape, Robert A. 1997. "Why Economic Sanctions Do Not Work." International Security 22 (2): 90-136.

Shi, Weiyi, and Brigitte Seim. 2021. "A Reputation Deficit? The Myths and Reality of Chinese Investment in Zambia." Journal of East Asian Studies 21 (2), forthcoming.

Skålnes, Lars S. 2000. Politics, Markets, and Grand Strategy: Foreign Economic Policies as Strategic Instruments. Ann Arbor, MI: University of Michigan Press.

Solingen, Etel. 1998. Regional Orders at Century's Dawn: Global and Domestic Influences on Grand Strategy. Princeton, NJ: Princeton University Press.

White, Hugh. 2011. "Power Shift: Rethinking Australia's Place in the Asian Century." Australian Journal of International Affairs 65 (1): 81-93.

Wong, Audrye. 2018. "More than Peripheral: How Provinces Influence China's Foreign Policy." The China Quarterly 235: 735-757.

_. 2019. "Crafting Payoffs: Strategies and Effectiveness of Economic Statecraft." Ph.D. diss., Princeton University.

- 2021. "How Not to Win Allies and Influence Geopolitics: China's Self-Defeating Economic Statecraft." Foreign Affairs (May/June 2021): 44-53.

Ye, Min. 2019. "Fragmentation and Mobilization: Domestic Politics of the Belt and Road in China." Journal of Contemporary China 28 (119): 696-711. 